STRUCTURE, PLACEMENT, AND UNIDIMENSIONAL PURITY

\title{
Structure, Placement, and the Quest for Unidimensional Purity in Typologies of American Denominations
}

Final version submitted to the Journal for the Scientific Study of Religion

\author{
BRIAN STEENSLAND \\ Department of Sociology \\ Indiana University-Purdue University Indianapolis
}

\author{
ROBERT D. WOODBERRY \\ Institute for Studies of Religion \\ Baylor University
}

JERRY Z. PARK

Department of Sociology

Baylor University

Correspondence should be addressed to Brian Steensland, Department of Sociology, Cavanaugh

Hall \#303, 425 University Boulevard, Indianapolis, Indiana, 46202. E-Mail: bsteens@iupui.edu. 


\section{INTRODUCTION}

Denominational affiliation is an important measure of religious belonging in the social scientific study of religion. In typologies of American denominations, much of the attention is devoted to Protestantism due to its size, complexity, and de-centered authority structure. One of the challenges in classifying Protestant denominations comes in reducing this complexity to a limited number of meaningful and useful categories. A different challenge arises from survey respondents' often-limited knowledge of their denomination and their under-specificity in reporting it.

Any classification system confronts two key questions. What is the best way to characterize the overall structure of American religion? And where should specific religious groups and categories of respondents be placed within this structure? Questions of structure and placement are interrelated, but for clarity's sake they should be treated as separately as possible when evaluating classification schemes.

We appreciate the opportunity to provide commentary on the coding scheme developed by Lehman and Sherkat (hereafter L\&S). They codify an approach to denominational classification developed by Sherkat and colleagues that overlaps in its logic with Roof and McKinney (1988) and Smith (1990) while also varying in structure, placement decisions, and terminology. In justifying their approach, L\&S critique the RELTRAD classification scheme (Steensland et al. 2000; Woodberry et al. 2012).

Here we comment on L\&S's approach and respond to their criticisms of the RELTRAD typology. We affirm the desire to have multiple classification schemes available for different 
STRUCTURE, PLACEMENT, AND UNIDIMENSIONAL PURITY

purposes. Yet we have concerns about the approach developed by L\&S - concerns that pertain to structure, placement, and their treatment of race/ethnicity. We also discuss new evidence that supports the RELTRAD approach, and we contextualize the debate over religious classification schemes as reflecting a longstanding desire for a unidimensional and pure denominational continuum. Our RELTRAD approach is nominal, not ordinal, and recognizes the thoroughgoing, real-world interpenetration of social characteristics and denominational affiliation. ${ }^{1}$

\section{Questions ConCerning Structure}

One of our chief concerns about the L\&S approach is the unclear conceptual and empirical basis for the sectarian-moderate-liberal structure they propose. Conceptually, the authors first reference Troelsch's "church-sect" continuum, which was based on multiple factors. They then praise Johnson's (1963) modification of Troelsch, which posits a church-sect continuum based on "tension with society" —namely, whether a religious group accepts or rejects the social environment in which it exists. L\&S then suggest an equivalence between Johnson's "tension with society" criterion and their criterion, which they call exclusivismuniversalism - i.e., whether a religious group claims to hold a monopoly on access to supernatural rewards or compensators. This criterion is different from Johnson's, though L\&S downplay this difference. Johnson's primary empirical referent for “tension with society" involves a group's stance toward society's "dominant value system," a distinctly this-worldly point of reference. L\&S also cite Iannaccone's (1994) research on strict churches as justification

\footnotetext{
${ }^{1}$ An updated version of the RELTRAD syntax can be found at www.reltrad.com. [Note to editor: We own this site, but need to wait until October to transfer this domain to WordPress.]
} 
for their approach. But Iannaccone's definition of "strictness" is also this-worldly in its focus on sociability and lifestyle, and therefore distinct from L\&S's exclusivism and its theological focus on supernatural rewards. Thus L\&S's continuum is different from the precedents they cite. Yet they elide these differences, which leads to conceptual slippage throughout their discussion.

So how should scholars identify exclusivist and universalist religious groups? Here we move from conceptual to empirical issues. Again we see a lack of clarity in L\&S's scheme. Notably, the General Social Survey does not contain a question about exclusivism and universalism. This means there is no way to directly assess the internal validity of this continuum using GSS data. Rather than testing their scheme with data from surveys that have questions about exclusivism-universalism, L\&S claim empirical justification from two external sources, which they cite as evidence of a "longstanding consensus" within the field. One of them is Iannaccone's (1994) study of behavioral strictness and sociability, which, as we discussed above, is different than exclusivism. L\&S's use of this study raises further questions. Iannaccone provides no criteria for sorting Protestant groups into categories such as "moderate" or "liberal." Further, his typology utilizes four categories — sect, conservative, moderate, and liberal. L\&S do not explain how they reconceptualize it as three categories. Finally, Iannaccone distinguishes between mainline and evangelical Baptists and Lutherans, an approach that L\&S criticize extensively. L\&S place all Baptists and all Lutherans in the same category, "sectarian” and “moderate," respectively. For all these reasons, the authors' use of Iannaccone (1994) as a precedent for their own approach raises a variety of concerns.

L\&S also reference a technical appendix to Hoge and Roozen's (1979) book on church growth as justification for their approach. We were not able to locate this technical appendix, which was printed separately from the edited volume, but the book's substantive chapters do not 
differentiate between "sectarian," "moderate" and "liberal" Protestants as distinctive and meaningful categories, nor do they provide a basis for distinguishing between groups on the basis of exclusivism of supernatural rewards. ${ }^{2}$ Roof and McKinney, chief popularizers of the distinction between "moderate" and "liberal" Protestants, admit that the distinction between the two groups is arbitrary (Roof and McKinney 1987:87). In sum, the evidence that L\&S cite for a "longstanding consensus" concerning sectarian-moderate-liberal Protestant groups arrayed along an exclusivism-universalism continuum is thin.

In the absence of a compelling external basis of their three-part typology, L\&S switch to criteria internal to the GSS. This leads to problems of false equivalence and circular reasoning. The only religious belief $\mathrm{L} \& \mathrm{~S}$ use to justify their scheme is biblical literalism. Views of biblical literalism and claims of exclusive monopoly on supernatural rewards are different. For example, the National Association of Evangelicals requires members to assert that Jesus is the only way to salvation, but does not require them to be biblical literalists. If biblical literalism is L\&S's chief empirical indicator, they should be straight forward and call their continuum a biblical literalism scale rather than treating biblical literalism and exclusivism as synonymous.

L\&S also use social attitudes (about gender, abortion, and homosexuality) and status markers (income and college degree) to analyze their continuum. But because they are creating

${ }^{2}$ Hoge's (1979) chapter testing theories of church growth and decline is presumably the closest to the relevant material in the appendix. He rates for 17 denominations along 8 dimensions, such as strength of ethnic identity, theological conservatism/liberalism, and attitudes toward ecumenicism. None of these dimensions pertain to exclusivism of supernatural rewards and Hoge makes no differentiation between "moderate" and "liberal" Protestants. 
STRUCTURE, PLACEMENT, AND UNIDIMENSIONAL PURITY

the continuum, not simply justifying it post facto, the continuum and the attitudes and status markers are not independent. This makes any causal claims about denominational affiliation and these types of measures invalid. L\&S engage in the type of circular reasoning we critiqued in “conservative-moderate-liberal” religious typologies in our original RELTRAD article (Steensland et al. 2000).

Beyond the conceptual and empirical concerns stated above, we also have concerns about terminology. One weakness of their terminology is descriptive. Why use the term "sect"? What does it mean to label the Southern Baptist Convention a "sect," when it is the largest Protestant denomination in the country and sets the cultural tone for an entire region? To be sure, presentday Southern Baptists are theologically conservative. They are socially conservative. They critique elements of mainstream society. But are they a sect? This label pushes the term beyond its useful descriptive limits. Applying it to groups such as Southern Baptists seems to primarily accomplish "othering."

The second problem with the terminology is that it obfuscates the conceptual basis of the typology. If "sect" appears at one end of the spectrum, why doesn't "church" appear at the other? If "liberal" appears at one end of the spectrum, why doesn't "conservative" appear at the other? L\&S's terminology is internally inconsistent. It conflates the sect-church continuum and the conservative-liberal continuum. Further, it masks the stated basis of the continuum, which is supposedly exclusivism-universalism.

Ultimately the rationale for the structure of L\&S's classification scheme is too opaque. Conceptually, the authors toggle between different dimensions: sect-church, exclusivistuniversalist, conservative-liberal and high class-low class. This muddled approach is reproduced in their internally inconsistent and inaccurate terminology. At the operational level, L\&S do not 
empirically measure their key concept: exclusivism-universalism. Instead, their empirical justification combines items that measure biblical literalism, worship attendance, social attitudes, and status hierarchy. In other words, their typology is based more on social ideology and Niebuhrian status characteristics than on exclusivism. This mix of factors risks circular reasoning and should be justified forthrightly, rather than being inaccurately described as based on "theological exclusivity-universalism."

\section{Questions Concerning Placement}

A distinguishing and puzzling feature of L\&S's taxonomy is treating entire denominational families as monolithic rather than acknowledging the diversity within them. This treatment ignores the historical reasons underlying the schisms and mergers these denominations have undergone. It ignores the institutional affiliation in the National Council of Churches and National Association of Evangelicals that many of these groups have. And it downplays the stated importance of exclusivism in favor of other factors, such as ethnicity and liturgical distinctiveness, to determine appropriate categorical placement.

L\&S classify all Baptists as sectarian. Yet by almost any measure, American Baptists should not be located at this end of the spectrum (whatever it is labeled). They are originating members of the Federal Council of Churches and current members of the National Council of Churches, both quintessential mainline bodies. Locally, American Baptist congregations often operate jointly with the United Church of Christ, a distinctly left-liberal group on theological and 
social matters. Further, L\&S classify all Presbyterians as liberal. ${ }^{3}$ This may be true for the Presbyterian Church (USA). Most other Presbyterian denominations, such as Orthodox Presbyterians, Cumberland Presbyterians, and the Presbyterian Church in America (or PCA), are theologically and socially conservative. They are decidedly non-liberal. Presbyterian schisms were central to the fundamentalist-modernist split in the early twentieth century. Finally, L\&S classify all Lutherans as moderate. The Evangelical Lutheran Church in America (ELCA), its name notwithstanding, is a mainline Protestant group and a member of the National Council of Churches. Other major Lutheran groups, such as Missouri Synod and Wisconsin Synod Lutherans, are conservative on theological and social issues, and are not members of the NCC. In each of these three cases, placing the various denominations together is the same category has no firm justification aside from treating denominations in the same denominational family as the same. L\&S's monolithic placement of these groups contradicts many existing typologies, including the Iannaccone (1994) paper they cite as precedent.

We undertook new analyses to evaluate the placement of Lutherans, Baptists, Presbyterians, and non-denominational Protestants. ${ }^{4}$ We used the 2008 Henry Institute Survey of Religion and Public Life because it contains measures of exclusivism-universalism, biblical

${ }^{3}$ L\&S attempt to justify this by claiming that Calvinists do not evangelize. But this is neither true historically or now. Examples abound. Presbyterians have long been active in overseas missions, and Tim Keller, one of the most well known evangelical pastors in the country, heads a PCA church planting network focused on missions.

${ }^{4}$ All subsequent analyses are available from the authors upon request. [Note to editor: We can also place this in an online supplement.] 
authority, preservation of religious tradition, support for missions, and religious identity. Where possible, we used multiple measures of these concepts. In doing so, we directly measured the criteria that L\&S say underlie their denominational taxonomy (exclusivism-universalism). We created general Evangelical, Mainline and Black Protestant categories following the RELTRAD approach, and then created categories for evangelical and mainline Presbyterians, Lutherans, and Baptists as well as for a "non-denom" category. We compared these specific groups against the general evangelical and mainline categories based on their exclusivism-universalism, views of biblical authority, and the other measures.

Our results show that the Lutheran, Baptist, and Presbyterian groups we coded as evangelical look very similar to other Evangelical Protestants, and quite different from Lutherans, Baptists, and Presbyterians we coded as mainline. ${ }^{5}$ Similarly, the denominational groups we coded as mainline look very similar to other Mainline Protestants and quite different from the counterparts we coded as evangelical. For instance, if we look at measures of exclusivism-universalism, 82 percent of evangelical Baptists strongly disagree with the statement that all the great religious traditions are equally true, whereas only 41 percent of mainline Baptists strongly disagree. This is similar to the overall difference between evangelical and mainline Protestants (71 percent and 42 percent, respectively). ${ }^{6}$ Similarly, 82 percent of

\footnotetext{
${ }^{5}$ Some of the cell sizes were small, but the patterns corroborate the RELTRAD coding. ${ }^{6}$ Percentages reported in this paragraph are for respondents who attend religious services once a week or more - i.e., people who are more exposed to their religious tradition. This avoids L\&S's criticism that some of the results using RELTRAD are due to using church attendance to code some respondents. The results are comparable if we use the full sample.
} 
evangelical Lutherans believe that Jesus is the only way to salvation, whereas 53 percent of mainline Lutherans believe the same. Again, this is similar to the overall difference between evangelical and mainline Protestants (85 percent and 64 percent, respectively), and between evangelical and mainline Presbyterians and Baptists. In sum, using direct measures of exclusivism-universalism, the RELTRAD approach captures meaningful differences between evangelical and mainline Lutherans, Baptists, and Presbyterians.

Another issue raised in L\&S's taxonomy is the placement of Christians who do not state a denominational affiliation - either because they attend a non-denominational or interdenominational church, because their church downplays its denominational affiliation, or because they are not closely affiliated with any religious group. These respondents present a challenge to any classification scheme due to under-specification. In the absence of sufficient denominational information, placement will inevitably be inexact, whatever the coding scheme. The RELTRAD approach uses attendance to sort these groups. Non-denominational respondents who attend church monthly or more are sorted into the evangelical category; other respondents are dropped as too ambiguous to code confidently. L\&S place unspecified Christian respondents in the "moderate" category based on the claim that non-denominational Protestants are not necessarily theologically conservative or evangelical.

Our analysis using the Henry Institute data confirms our original RELTRAD coding. On exclusivism-universalism, biblical authority, preservation of religious tradition, support for missions, and religious movement identity, non-denominational Protestants who attend church once a month or more are nearly identical to evangelicals who attend church once a month or more. Conversely, non-denominational respondents who attend church less than once a month are distinct from evangelicals who attend less than once a month. 


\section{RACE AND ETHNICITY}

Race and ethnicity are social characteristics that impact and intersect with denominational affiliation. So we briefly highlight three notable elements of L\&S's scheme regarding race/ethnicity and address some of their related criticisms of the RELTRAD approach.

The authors place all the denominations in the Black Protestant tradition in the "moderate" category, including AME and AMEZ denominations. Arguably Black Protestants could be placed in the "liberal" category based on political affiliation and economic attitudes, or in the "sectarian" category based on biblical literalism and conservative views on social issues. L\&S's placement is not well explained. And while L\&S criticize RELTRAD for placing respondents in the Black Protestant traditions in a single group, they place them all in the "moderate" category. One consequences is that their sectarian and liberal groups are whiter than they would be if L\&S consistently used exclusivism to code denominations. Another is that one of the most important social pillars of African American life and progress is rendered invisible.

Also curious is that Tables 1 and 5, which L\&S use to justify their taxonomy, include only white Christians. For a classification scheme that seeks broad application—broader than the white population - this is puzzling and requires explanation. One reason may be that the inclusion of non-whites muddies the distinctions between groups that the authors want to draw.

Finally, as we discussed above, L\&S use race and ethnicity as a basis for placing all black Protestants and Lutherans together. This is notable because it belies claims that their measures are "independent" of social factors and based solely on theology.

The authors also make incorrect statements about race in the RELTRAD scheme. We discuss the place of race in the RELTRAD taxonomy in Woodberry et al. (2012). The authors 
cite this article, but seem to ignore the discussion therein. They would also benefit from reading Shelton and Cobb's (2018) recent elaboration of RELTRAD to differentiate African American religious groups.

To respond to L\&S in brief: We do not, as a general rule, use respondents' race as a basis for placement in the Black Protestant category. This category does not contain blacks who are Protestant. It contains respondents who affiliate with one of the historical "black church" denominations. If a respondent is black and United Methodist, they are classified as mainline Protestant. We commend the label that the Pew Research Center uses for this category"historically black Protestant"—-because it highlights this denominational logic more clearly than our original label. Similarly, a white respondent who attends an AME church is classified as having a Black Protestant affiliation. It is not a coding error; it follows the logic of the RELTRAD scheme, which to the extent possible classifies people based on their denominational affiliation, not their demographic characteristics. We only use demographic traits to code some Baptist and unspecified Methodist respondents, and respondents with no identifiable denominational affiliation. In these more limited cases we use attendance and race as a basis for placement. In the absence of more specific denominational information, we stand by this approach.

\section{The Quest For Unidimensional PuRity}

Taking a step back from the specifics of the L\&S taxonomy, we see an impulse underlying their scheme that is shared by many social scientists who study religion. This is the desire for a powerful but parsimonious measure of religious identity or belonging that varies 
across a single continuum and is based on criteria outside other commonly studied social attributes.

Yet this goal is difficult to reach using existing survey measures. We have already discussed one reason above: the problem of under-specification by respondents. Another reason is conceptual. There is an inevitable tension between classification schemes that seek to develop "pure" categories that can serve as the basis for statistical interactions and conceptually rich approaches to intersectionality, and the desire for schemes that adequately capture the historical and real-world interpenetration of religious affiliation, socio-economic class, racial and ethnic identity, geographical region, and so forth. This interpenetration is "baked in" to the American denominational system; it cannot be artificially teased out using denominational affiliation alone. $^{7}$

This tension makes constructing classification schemes challenging. Denominational typologies will always fall short in some way because competing and equally valid criteria for evaluation pull in different directions. But rather than acknowledging this challenge, L\&S muddy the waters by framing their approach as "pure," based on a single axis of exclusivismuniversalism, while operationalizing and justifying it using a host of other factors - e.g., biblical literalism, social attitudes, social class, race/ethnicity, liturgical worship. They make mutually inconsistent claims in back-to-back sentences. They claim that their Protestant grouping is "based on theological exclusivity and universalism," but the next sentence states that their scheme "disconnects" religious identification from particular theologies or religious practices" (20-21). A paragraph later they claim that their approach "maintains the independence of

\footnotetext{
${ }^{7}$ For a complementary perspective, see Wilde (2018).
} 
religious identifications and other social identities" (21). This claim is a claim of unidimensional purity. But as we have shown throughout our commentary, it is inaccurate.

In sum, L\&S are claiming a superiority that their approach does not bear out. They claim to be creating a classification scheme that is pure and independent of belief and other social factors. We understand the impulse behind these claims, but this does not make the statements any less erroneous.

\section{CONCLUSION}

The RELTRAD approach is based on nominal religious categories that acknowledge the history, institutional ties, beliefs, and practices that are bound up in religious traditions. Lehman and Sherkat offer an approach to classifying Protestants that is distinct from RELTRAD. We identify concerns about their approach and responded to questions and mischaracterizations about our own. In the end, classification schemes are pragmatic tools. In our view, L\&S are not clear about the problems that their scheme addresses or fixes. But we affirm the potential benefits of having multiple classification schemes available to scholars.

We also understand the desire for a powerful unidimensional coding scheme. We do not believe this can be accomplished solely with existing denominational measures in surveys like the GSS. But it could perhaps be developed using completely separate measures that are then employed systematically and transparently to locate individual denominations (not entire denominational families) along a continuum of some sort. Read sympathetically, this is the core of what L\&S sought to do. We believe this goal can perhaps be more fully actualized in the future. 


\section{REFERENCES}

Hoge, Dean R. 1979. A test of theories of denominational growth and decline. In Understanding Church Growth and Decline, 1950-1978, edited by Dean R. Hoge and David A. Roozen, pp. 179-96. New York, NY: Pilgrim Press.

Hoge, Dean R., and David A. Roozen. 1979. Understanding Church Growth and Decline, 1950-1978. New York, NY: Pilgrim Press.

Iannaccone, Laurence R. 1994. Why strict churches are strong. American Journal of Sociology 99:1180211.

Johnson, Benton. 1963. On church and sect. American Sociological Review 28(4):539-49.

Roof, Wade Clark and William McKinney. 1987. American Mainline Religion: Its Changing Shape and Future. New Brunswick, NJ: Rutgers University Press.

Shelton, Jason E. and Ryon J. Cobb. 2018. Black Reltrad: Measuring religious diversity and commonality among African Americans. Journal for the Scientific Study of Religion 56(4):73764.

Smith, Tom W. 1990. Classifying Protestant denominations. Review of Religious Research 31(3):22545.

Steensland, Brian, Jerry Z. Park, Mark D. Regnerus, Lynn D. Robinson, W. Bradford Wilcox and Robert D. Woodberry. 2000. The measure of American religion: Toward improving the state of the art. Social Forces 79(1):291-318.

Wilde, Melissa. 2018. Complex religion: Interrogating assumptions of independence in the study of religion. Sociology of Religion 79(3):287-98.

Woodberry, Robert D., Jerry Z. Park, Lyman A. Kellstedt, Mark D. Regnerus and Brian Steensland. 2012. The measure of American religious traditions: Theoretical and measurement 
STRUCTURE, PLACEMENT, AND UNIDIMENSIONAL PURITY

considerations. Social Forces 91(1):65-73. 